\title{
A MAGYAR BANKSZÖVETSÉG ELSŐ HÁROM ÉVTIZEDE
}

Kovács Levente

Az 1989-ben megalakult Magyar Bankszövetség három évtizedes múltját és tevékenységét mutatjuk be saját bankári látásmódunk szerint. A részletes ismertetést 5 évvel ezelötti könyvünk (Müller J. - Kovács T. - Kovács L. (2014): A Magyar Bankszövetség története) elvégezte, így most egy rövid összefoglalásra törekszünk. Célunk, hogy köszöntsük az évfordulót, dióhéjban bemutassuk azt a tevékenységet, amelyet végeztünk, illetve végzünk, továbbá megköszönjük a szektorban, a szektorért végzett bankári és bankszövetségi munkát. Ennek érdekében az elmúlt három évtizedet fejlődési szakaszokra bontottuk, minden egyes szakasznak megadtuk a legfontosabb kihívásait, és bemutattuk az elvégzett feladatokat. Ennek tükrében bizton állíthatjuk, hogy a bankári munka nehéz, kívülről erkölcsi elismerésben ritkán részesített, belülről azonban szép, kihívásokkal teli és a gazdasági fejlődéshez nélkülözhetetlen.

JEL-kód: $\mathrm{N} 94$

Kulcsszavak: Magyar Bankszövetség, évforduló, banktörténet

\section{A BANKI ÉRDEKKÉPVISELET MEGSZÜLETÉSE}

A bankok és pénzintézetek hagyományosan rendelkeznek érdekképviseleti szervezetekkel. Amikor egy nemzetgazdaság önállóvá, függetlenné válik, akkor a megerősödéséhez, a gazdasági növekedéséhez aktív hitelintézetekre van szükség. Ekkor a bankok előtt is tér nyílik, így a bankszektor és a gazdaság szimbiózisban erősödik és építi fel az új, korszerű nemzetgazdaságot. A betétesek pénzét közvetítő, pénzt teremtő bankszektor speciális vonásokkal bír, ezért tevékenységét nem a szabadpiaci lehetőségek, hanem igen részletesen szabályozott és felügyelt keretek között végezheti. Kiemelten a szabályozottság az, ami miatt a bankszektor saját érdeke az egységes érdekképviselet létrehozása, amelynek célja:

- „a hitelintézeti szektor szakmai egyeztetési, véleménynyilvánítási fórumaként érdekképviseleti tevékenységével segítse tagszervezeteinek munkáját,

- a hitelintézeti szektor működését és fejlődését segítő, versenysemleges közgazdasági és jogi szabályozási környezet valósuljon meg,

- tevékenységével hozzájáruljon a hitelintézeti szolgáltatások színvonalának növeléséhez, az ügyfelek bizalmának erősödéséhez, a tisztességes piaci verseny élénkítéséhez." (MBSZ Alapszabály 2. \$. 1. pont) 
Ez így volt a múltban is. Magyarországon 1903-ban megalakult a Pénzintézetek Országos Egyesülése (POE), majd további jelentős egyesületek, így a Bankárok és Értékpapírkereskedők Országos Egyesülete, a Magyar Pénzügyi Szindikátus és a Takarékpénztárak és Bankok Egyesülete (Müller-Kovács-Kovács, 2014:10). Ez utóbbi egyesület (mozaiknevén a TÉBE) vált a 20. század első harmadának végére - a POE beolvadása (1928) után - a bankszektor meghatározó érdekképviseletévé. A TÉBE - egyebek mellett - a trianoni béketárgyalásokra szakmai anyagokat készített, tulajdonosi részt vállalt a Magyar Nemzeti Bank megalapításában, jelentős támogatással biztosította a Magyar Nemzet napilap elindítását, 1923-ban nyugdíjpénztárt alapított, a szintén 1923-ban alapított kiadóvállalata pénzügyi könyvek százait adta ki, családvédelmi és szociálpolitikai lépéseivel évtizedekkel előremutatott, átvette az 1912-ben alakult pénzintézeti sportegylet menedzselését is (Vértes, 1940:217-218; Pethő, 2008; Előjegyzési Napló, 1939).

A második világháborút követően a bankokat államosították, a TÉBE-t megszüntették.

Hosszú szünet következett. Több előremutató, de végigvitelében megakasztott pénzügyi és gazdasági reformpróbálkozás után, 1987-ben - a szocialista táboron belül elsőként Magyarországon - jöhetett létre a kétszintű bankrendszer. A következő évben már kezdeményezték is a „bankok és pénzintézetek szakmai szövetsége” létrehozását egy, az akkori szokásoknak megfelelően „elvtársi üdvözlettel" aláírt levélben (A bankszövetség létrehozásának előkészítő dokumentuma, 1988. nov. 22.). A bejegyzésről a következö évben. 1989. február 28-án meg is jött a Fővárosi Bíróság végzése. Azóta ezt a napot tekintjük a Magyar Bankszövetség megalapítása dátumának. Azonban nem feledkezhetünk meg arról sem, hogy a Magyar Bankszövetség szellemi elődjének tekinti az 1919-ben megalapított, idén százéves TÉBE-t. Azaz egyrészt 30, másrészt 100 éves bankszövetségi érdekképviseleti évfordulót ünnepelünk 2019-ben.

A Magyar Bankszövetségnek 24 alapító tagja volt, köztük 22 bank. Az első hónapokat az induló szervezetekre jellemző keretek kialakítása határozta meg. Ezt az időszakot Pulai Miklós főtitkári megbízatása zárta le, aki szakmai múltja és tekintélye révén a bankszektor müködtetéséhez szükséges jogi, szabályozási és felügyelési keretek konszenzusos kialakítására helyezte át a hangsúlyt, ezzel kezdődött el a valódi érdekképviseleti munka. 


\section{A MAGYAR BANKSZÖVETSÉG MÜKÖDÉSI SZAKASZAI ${ }^{1}$}

\subsection{A Magyar Bankszövetség a rendszerváltás idején (1987-1993)}

Bár a kétszintű bankrendszer az úgynevezett szocialista rendszer gazdasági rendjén belül a változások előfutára volt, ugyanakkor a rendszerváltozásig egy ellehetetlenült gazdasági és politikai modell végső vergődése közepett müködött. Az 1990-es szabad választással került az ország élére legitim vezetés, amely elkezdte a gazdaság gyökeres átalakítását. Ennek részeként 1990-ben egy tárca nélküli minisztert, Botos Katalint bízták meg a bankrendszer fejlesztésével, az új szabályozási környezet kialakításával. Ebben a folyamatban az érdekképviselet révén igen szoros kormányzati együttműködés jellemezte a Bankszövetség munkáját, hiszen a politikai vezetéssel együtt kellett új, működőképes pénzügyi rendszert és környezetet kialakítani.

A keretek létrehozása után szembe kellett nézni azzal, hogy a szocialista időszak politikailag irányított vállalati hitelezése még a problémák elfedésére sem volt elegendő. A hitelek visszafizetésére reálisan számítani nem lehetett. A bankszektor iránti bizalom megőrzése, a bankok hitelezési képességének a helyreállítása érdekében a szocialista örökségü bankrendszert konszolidálni kellett. A bankok konszolidációját, feltőkésítését követően lehetett csak a mai gyakorlat felé mutató, felelősségteljes bankári munkát elkezdeni.

Ekkorra jött el az ideje annak, hogy a bankok - az állam által létrehozott szabályozási keretek között - a szektor számára szükséges háttérintézményeket, így hitelintézeti elszámolóházat, hitelgaranciát, központi adósnyilvántartó céget, betétbiztosítási alapot stb. hozzanak létre. A Magyar Bankszövetségnek a háttérintézmények kialakításában, a kapcsolatok és a müködési keretek kialakításában fontos szerep jutott. Visszatekintve valószínűsíthetjük, hogy erősebb érdekérvényesítési lehetőséget és kiszámíthatóbb működtetést biztosított volna, ha a Bankszövetség - a környező országokhoz hasonlóan - tulajdonosként is meghatározó szerepet vállalt volna ezen intézmények megalapításában, elindításában, majd müködtetésében.

\subsection{Stabilizálódó bankszektor (1994-2000)}

A bankkonszolidáció biztosította azt, hogy a kereskedelmi bankszektor immár piaci alapon, felelős bankszakmai irányítással végezhesse a munkáját. A piaci alapon müködő bankszektor minden országban kedvező befektetési célpont volt elsősorban szakmai befektetők számára. A bankházak arra törekedtek - és ez ma

1 KovÁcs, 2017:15 felosztása alapján 
sincs másképp -, hogy egy-egy régiót homogén módon fedjenek le, és ott ügyfeleiket egységes színvonalon szolgálják ki. Ezzel segítik elő ügyfeleik regionális, nemzetközi terjeszkedését. A kormányzat extra bevételi igényei és a nemzetközi bankházak regionális terjeszkedési céljai így egymásra találtak; ennek eredményeként a magyar bankszektor jelentős része külföldi befektetők kezébe került. A privatizálás meglehetősen széleskörüre sikeredett, hiszen érdemben csak az OTP-t sikerült tőzsdei bevezetéssel magyar menedzsment alatt tartani. Ennek jelentőségét csak hosszú idővel később értették meg a politikusok, amikorra a Csányi Sándor által vezetett OTP Bank átalakítása, hazai pénzpiaci aktivitása és nemzetközi terjeszkedése megkérdőjelezhetetlen sikerként vonult be a magyar gazdaságtörténetbe.

A privatizált bankok esetében érdemes kiemelni, hogy jellemzően egy-egy nagy nemzetközi bankház szerves részeivé váltak. Így átvették az adott bankház szervezeti, működési és irányítási modelljét, megkapták az informatikai fejlesztéshez a támogatást, hitelezésükhöz a szükséges tőkét és kockázatkezelési tudást, valamint betéteseik bizalmát és az aktív bekapcsolódás lehetőségét a globális pénzpiacok müködésébe. Ezek hatására a bankszektor fejlődése jóval megelőzte a reálszféra átalakítását, így a bankszektor dinamikusan húzta, ösztökélte a gazdasági szereplőket. A bankszektor társadalmi megbecsülése megerősödött, és némi túlzással élve mindenki ettől várta a gazdaság további gyors felfejlesztését.

Eközben a háttérintézmények is aktivizálódtak, és segítették a gazdaság gyors átállását. Így elindult az elektronikus pénzforgalom, bevezették a bankkártyákat, kiépítették az elfogadó terminálokat és a bankjegykiadó automaták hálózatát, stb. A korábbi, az elindulást biztosító szabályozások is tovább finomodtak, megjelent az új hitelintézeti, az értékpapírpiaci, a szakosított hitelintézeti törvények. Ebben az időszakban a Magyar Bankszövetségben megerősödtek a munkacsoportok, amelyek szorosan együttműködtek a releváns kormányzati szervekkel az új jogszabályok véglegesítésében.

\subsection{Felkészülés az EU-csatlakozásra (2000-2004)}

A magyar társadalom az EU-csatlakozásban az európai integrálódást, a NyugatEurópához való felzárkózás lehetőségét láthatta. Így nagy reményekkel készült erre, a csatlakozási népszavazás is elsöprő sikert, 84\%-os támogatást hozott.

A csatlakozást többéves felkészülési folyamat előzte meg. Ez a bankszövetségi tevékenységre nézve - az előző időszak szempontjainak lehetőség szerinti érvényre juttatása mellett - az európai megfelelőség biztosítását jelentette.

Ebben az időszakban az első Orbán-kormány új lakáspolitikája hozott érdemi banki változást, hiszen hosszú kihagyás után a kormányzati támogatások beindí- 
tották a forintalapú lakásfinanszírozást. Ennek elsődleges kedvezményezettjei a magyar családok voltak, s örömmel konstatálhatjuk, hogy ez a lakáshitel-portfólió az elmúlt évtizedek legjobb minőségű portfóliója.

$\mathrm{Az}$ EU-csatlakozás természetesen lényegi előrelépést hozott a Magyar Bankszövetségnek az európai bankszövetségek szövetségében, a European Banking Federationben végzett munkájában. Ugyanis a korábbi „associates” státuszt követően a Magyar Bankszövetség 2014. január 7-én kelt teljes jogú tagsági kérelmét már az ország hivatalos csatlakozása előtt elfogadták. Ettől kezdve a Magyar Bankszövetség aktívan részt vesz az európai bankok brüsszeli érdekképviseleti munkájában.

\subsection{Az EU-csatlakozástól a gazdasági válságig (2004-2008)}

Az európai csatlakozás tovább bővítette a magyar gazdaság szereplői előtt a nemzetközi megjelenés lehetőségét. Ennek a támogatására a bankszektor készen állt, a hazai bankszektor az európai és a nemzetközi pénzpiacokon aktív tevékenységet folytatott, a pénzpiacok likvidek voltak, a digitális bankolás immár lakossági körben is általánossá vált. Mindezek hatására fokozódott a bankok közti verseny is. Következésképp csökkentek a kamatfelárak, a banki díjak és a jutalékok, folyamatosan bővült a termékspektrum és nőtt a szolgáltatási színvonal.

Mindemellett az EU-csatlakozás előnyeit a magyar gazdaságnak kevéssé sikerült realizálnia, így a gazdasági növekedés megrekedt, a magyar kamatszint magas maradt, a költségvetés pedig hiánnyal küszködött.

A kormány megszorításokkal próbálta rendezni a költségvetés helyzetét, ezért eltörölték a lakáshitelek kamattámogatását is. A társadalom lakástulajdon-szerzési vágya fennmaradt, azonban a kamattámogatás nélküli forinthitelek magas kamatszintje csak keveseknek jelentett valós finanszírozási alternatívát. Ezek a körülmények hívták életre a közvetítő devizán (jellemzően svájci frankon) keresztül nyújtott hitelek iránti igényt. A magas kamatszint/infláció mellett a devizaalapú hitelek előnye az, hogy a törlesztőrészlet jóval alacsonyabb szintről indul, viszont nem inflálódik el, és jelenértékben közel állandó marad. Ezt a kedvező hatást átmenetileg tovább fokozta, hogy a magasan tartott kamatszint mellett és részben amiatt a forint folyamatosan felértékelődött. Azaz a devizaalapú hitelek törlesztőrészlete még forintban is csökkent! A devizaalapú hitelezés veszélyeire a bankszektor ugyan többször felhívta a vezetők és kockázatfeltáró nyilatkozatban az ügyfelek figyelmét is, azonban a verseny háttérbe szorította a jövőre vonatkozó, kötelező óvatosságot, és szabályozási korlátozás sem következett be. A devizaalapú hitelek gyors térnyerése és ezzel az építőipar mesterséges felfuttatása pedig éppen jókor jött a gyengélkedő gazdaságnak, hiszen enyhítette a munkanélküliséget, és extra költségvetési adóbevételt hozott. 


\subsection{A gazdasági válság és árnyékhatása (2008-2015)}

A gazdasági válság kiváltó okáról, hatásairól már sokan írtak. Bankszövetségi szempontból a válság azt jelentette, hogy a hitelintézeti tagság körében jelentős portfólióromlás következett be, amit bizalmi válság, tőkepótlást megkövetelő veszteségképződés és hatósági oldalról túlszabályozás követett. A bankszektor szerepe, lehetősége, feladata jelentősen átalakult, ami új típusú érdekképviseletet tett szükségessé. Itt érdemes is megállni.

Korábban a bankárok jellemzően emberöltőkre terveztek, s kissé le is nézték a csak rövid ciklusokban gondolkodókat. Nem utolsó sorban a bankvezetés némi önkényes döntéshozatali mechanizmussal is együtt járt, és befolyását a politikai döntéshozókéval azonosként tételezte. A gazdasági válság és következményei ennek a korszaknak vetettek véget. Ezt röviden és velősen fejezte ki Patai Mihály, a Bankszövetség elnöke, amikor azt mondta, hogy ebben az időszakban a politikai elit visszavette a primátusát (Patai, 2011). Az új modus vivendi kialakítása természetesen nem történhetett zökkenőmentesen, egyebek között az időszak szociális, bizalmi és gazdasági kihívásai miatt sem.

A gazdasági válság hatására a magyar bankszektor is kedvezőtlen pályára került: csökkent a bankszektor mérlegföösszege, a szektor tartósan veszteségessé vált. A devizahiteles problémák és programok költségei miatt elvesztette tőkéjének egyharmadát, továbbá újonnan ráhárított kötelezettségként bizonyos takarékszövetkezetek, ilyen eredetű bankok és egyes brókercégek felszámolásának költségviselésére is rákényszerült, így elvesztette régiós versenyképességét. Ezen időszak tagadhatatlan pozitívuma volt a lakossági devizaalapú hitelek jó ütemben végrehajtott forintosítása, amely a későbbi drasztikus árfolyamváltozások kedvezőtlen hatásait megelőzve, 2015 óta mintegy 450 milliárd forint tehertől mentesítette a magyar lakosságot. Ezen túlmenően a recesszióból a kilábalás felé vezető utat elsőként a Magyar Nemzeti Bank programjai rajzolták fel.

\section{6. Újjáépítés az árnyék után (2016-2019)}

A korábbi évek áldozatvállalása, a kedvező nemzetközi környezet, a politikai stabilitás, a hit a fejlődésben, a bizalom visszaszerzése mind-mind hozzájárult ahhoz, hogy egy új korszakról beszélhessünk. Ebben az időszakban a hitelezés, kiemelten a lakossági hitelezés újra erőteljes növekedésnek indult. A családpolitikai kérdésekben kialakuló kormányzati stratégia új távlatokat nyitott meg. A GDP növekedésben a KKE-régióval együtt Magyarország is gyors felzárkózásba kezdett. A költségvetés helyzete tartósan rendeződött, így a bankszektorra kivetett extra terhek is lassanként csökkeni kezdtek, azonban még mindig jelentős súllyal nehezednek a szektorra. 
Mindezzel párhuzamosan a hazai bankszektorban immár új tulajdonosi arányok jöttek létre, a szektor több mint 50\%-a magyar tulajdonba került, illetve magyar központi irányítással működik. A bankszektor ismét nyereséges, növekszik, az OTP Csoport pedig folytatja régiós térhódítását.

A devizahiteles jogkérdés véglegesen lezárult, hiszen annak társadalmi súlya és a kormány elkötelezettsége miatt a megoldási lehetőségeket csakúgy, mint a jogi aspektusokat legalaposabban Magyarországon járták körbe. Az Európai Bíróság 2018. év végi döntése már nem tartalmazott újdonságot a Kúria korábbi állásfoglalásához képest.

Az új gazdasági eredmények, a politika irányai és az európai harmonizációs követelmények a Magyar Bankszövetség feladatait is mind sokrétűbbé tették. A bankszektor működését befolyásoló szabályozói környezet az elmúlt években nagyságrendekkel összetettebbé vált, és a Bankszövetség érdekképviseleti tevékenységének is igazodnia kellett az új kihívásokhoz, közülük is kiemelten a fogyasztóvédelmi szempontok fokozott figyelembe vételéhez. A megnövekedett érdekérvényesítési, szakmai elemző, felkészítő és egyeztetési munkát a Magyar Bankszövetség immár ötven munkacsoportjának a bankok által delegált tagjai és a bankszövetségi munkatársak végzik az elnökség felügyeletével és számos ügyben meghatározó, érdemi személyes részvételével. Új kihívásaink között tartjuk számon az EU-s jogharmonizációs, valamint a világban tapasztalható digitalizációs boom jelentette és az ehhez kapcsolódó szabályozási feladatokat, továbbá a nemzetközi szervezetekkel való együttmüködés és az ezekben való szerepvállalás kötelező fejlesztését. A következő évtized is magas szakmai igényességgel és izgalmasan indul.

\section{A HÁROM ÉVTIZED SZÁMOKBAN}

A bankszövetségi munka és feladat szakaszolása alapján két dolgot láthatunk: a gazdasági és gazdaságpolitikai fejlődés meglehetősen tekervényes utat járt be, és ez folyamatos megújulást igényelt. Ezt a bankok még inkább a bőrükön érezhették, talán többször felsejlett bennük az ismert mondás: nem az a legény, aki üt, hanem aki állja! Ahhoz, hogy ezt érzékeltessük is, két grafikont szeretnénk bemutatni.

Az 1. grafikonon folytonos vonallal a bankszektor mérlegföösszegének alakulását láthatjuk az elmúlt három évtizedben. A bankszektor aktivitását leginkább ez a mutató fejezi ki, hiszen nemcsak a hitelállományra utal, hanem az adott bank méretét, illetve a gazdasági életben betöltött szerepét is jól érzékelteti. A pénzforgalom alakulását pedig a szürke vonal mutatja az elektronikus elszámolásforgalom 
elindulásától. Erre a mutatóra az elmúlt évtizedben figyeltünk igazán fel, hiszen ez a gazdasági előrejelzések mellett a bankszektor üzleti beágyazottságát is jól érzékelteti (Pál, 2013).

\section{1. grafikon}

A magyar bankszektor mérlegföösszege (1989-2018) és az elektronikus bankközi átutalások összesített értéke (1994-2018)

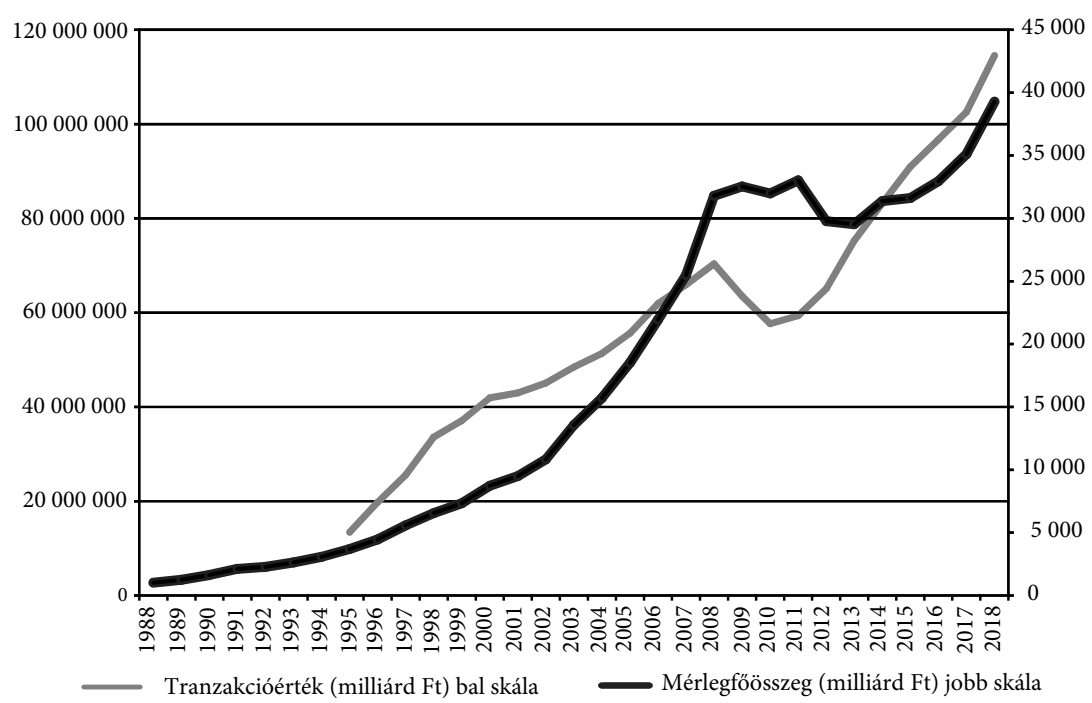

Forrás: Magyar Bankszövetség és GIRO Zrt.

A 2. grafikon a bankszektorban dolgozó munkatársak számát mutatja be. Az elmúlt évtizedekben mindkettő gyors emelkedést mutatott, melyet csak a 2008-as globális gazdasági válság átmenetileg megtörni. 


\section{2. grafikon}

A bankszektor munkatársainak a száma (1998-2018, ezer főben)

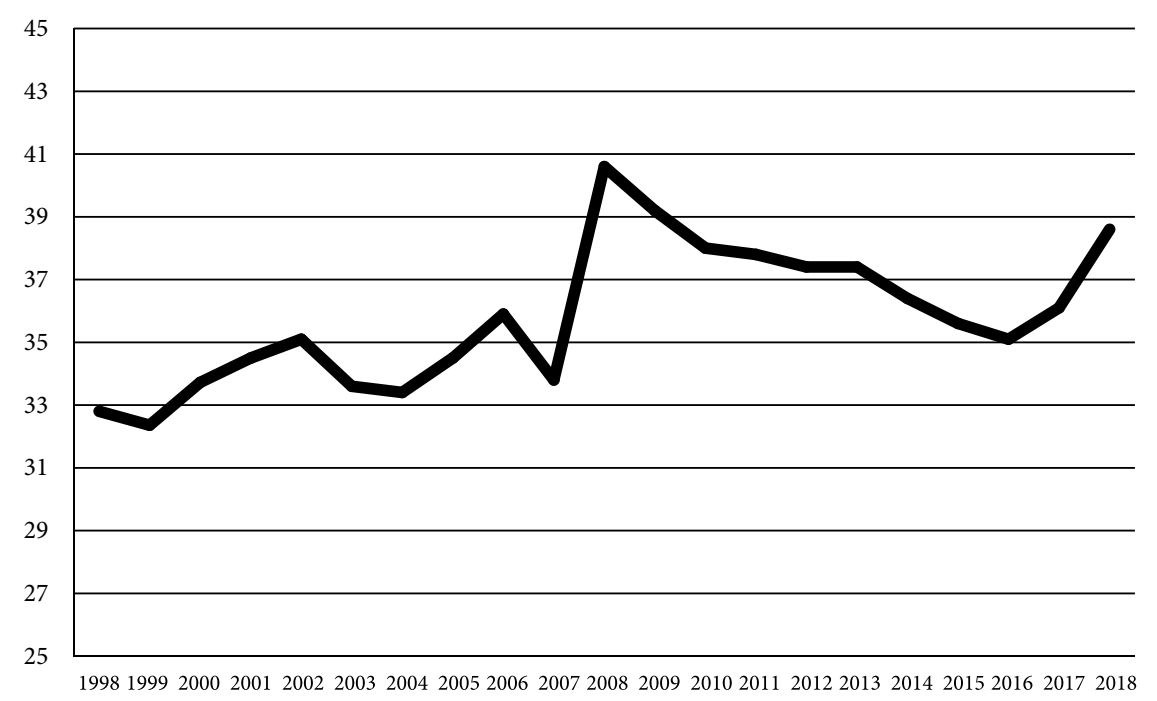

Forrás: KSH

A grafikon kapcsán a következő tényezőkre hívjuk fel a figyelmet: a fiókok számának és a jelzáloghitel-aktivitásnak az ezredforduló tájékán tapasztalt növekedése, majd a gazdasági válság alatti és az azt követő időszakában tapasztalt csökkenése értelemszerűen a munkatársak számában is megjelent; a digitalizálódás hatása közép- és hosszú távon előrejelzésünk szerint létszámcsökkenést eredményez.

Az elmúlt három évtizedben a bankszektor szerepvállalása és gazdasági aktivitása tízszeresére nőtt, miközben a munkatársak száma alig (kb. 10\%-kal) emelkedett. Így egy-egy banki munkatársra egyre több feladat hárul, azaz a munkaterhelés évtizedek óta folyamatosan nő.

\section{A MAGYAR BANKSZÖVETSÉG SZEREPVÁLLALÁSAI, TOVÁBBÁ TISZTSÉGVISELÖI, MUNKATÁRSAI (1989-2019) ÉS TAGJAI (2019. ÁPRILIS 5-ÉN)}

A Magyar Bankszövetség a tagság teljes körü és átfogó képviselete érdekében a pénzügyi szféra széles spektrumában látja el érdekképviseleti feladatát.

Ennek megfelelően tagjai közé tartoznak a hitelintézeteket kiszolgáló intézmények is, így a hitelintézeti elszámolóház (GIRO Zrt.), az értékpapír-elszámolóház és értéktár (KELER Zrt.), az adósnyilvántartás szolgáltatója (BISZ Zrt.) és a hitel- 
garancia-szervezetek (GHG, AVHGA). A teljes pénzügyi szektor érdekképviseletében vállalt, meghatározó szerepét mutatja az is, hogy a társ-érdekképviseleteket tagjai között tudhatja; így az Országos Takarékszövetkezeti Szövetséget 2008-tól 2018-ig, 2017-től a Pénzügyi Vállalkozások Országos Egyesületét és 2019-től a Magyar Lízingszövetséget is.

Az átfogó érdekképviselet növelése érdekében az MBSZ 2013-tól befogadta a Magyar SEPA Egyesület tevékenységét, majd 2016-tól a Magyar Jelzálogbank Egyesület munkáját. Szintén 2016-tól a SWIFT nemzeti felhasználói csoport koordinálását is biztosítja. 2002 és 2017 között társalapítóként működtette a Pénz- és Tőkepiaci Állandó Választott Bíróságot. A hazai pénzügyi kultúra fejlesztése érdekében 2015-től csatlakozott az EBF Money Week páneurópai rendezvénysorozatához; a Bankszövetség által alapított magyar pénzügyi kultúra hete, a „Pénz7” 5 év alatt a kormányzat és a jegybank által támogatott közprogrammá vált.

Az európai, illetve globális pénzügyi szféra vérkeringésében való részvételét segíti, hogy a Bankszövetség 1991-től levelező, 1998-tól társult, majd 2004-től teljes jogú tagja az Európai Bankföderációnak (EBF-nek). A jelzálogbanki érdekképviselet átvételével 2016-tól tagja az Európai Jelzálog Föderációnak (EMF) és a mellette működő Európai Fedezett Kötvény Tanácsnak (ECBC-nek). 2014-től ellátja a magyar érdekek képviseletét a páneurópai fizetési forgalom szakmai irányítására létrehozott Európai Pénzforgalmi Tanácsban (EPC). Szintén 2014-től alapító tagként vesz részt az Ázsiai Pénzügyi Együttműködési Szövetség (AFCA) munkájában. 2017-ben csatlakozott az EBF mellett müködő Európai Pénzpiaci Intézethez (EMMI), amely az euró-referenciakamatok menedzselését biztosítja.

A Bankszövetség életében jelentős szerepet vállaló személyekről sem szeretnénk megfeledkezni, ezért a következő táblázatokba rendezve megadjuk azoknak a neveit, akiknek a magyar gazdasági fejlődés pénzügyi támogatásában és kiszámíthatóságában, a bankszektor együttes szerepvállalásában jelentős szerepe volt. 
1. táblázat

Tisztségviselőink és tagintézményeink

\begin{tabular}{lcll}
\hline \multicolumn{3}{c}{ Elnökök } \\
\hline $\begin{array}{l}\text { Lenk Géza } \\
\text { (K\&H Bank) }\end{array}$ & $1989-1993$ & $\begin{array}{l}\text { Felcsuti Péter } \\
\text { (Raiffeisen Bank) }\end{array}$ & 2008-2009 \\
$\begin{array}{l}\text { Erdély Zsigmond Gábor } \\
\text { (MKB Bank) }\end{array}$ & $\begin{array}{l}\text { Patai Mihály } \\
\text { (UniCredit Bank) }\end{array}$ & $\begin{array}{l}\text { 2011-2012 és } \\
\text { 2013- } \\
\text { Erdei Tamás }\end{array}$ \\
$\begin{array}{l}\text { (MKB Bank) } \\
\text { 1997-2008 és }\end{array}$ & & \\
\hline
\end{tabular}

\begin{tabular}{lcll}
\hline \multicolumn{4}{c}{ Alelnökök } \\
\hline $\begin{array}{l}\text { Birmann Erzsébet } \\
\text { (Innofinance Rt) }\end{array}$ & $1989-1992$ & $\begin{array}{l}\text { Gyuris Dániel } \\
\text { (FHB Bank, } \\
\text { OTP Jelzálogbank) }\end{array}$ & $\begin{array}{l}\text { 2005-2008, } \\
\text { 2011-2014 }\end{array}$ \\
$\begin{array}{l}\text { Erős János (Általános } \\
\text { Értékforgalmi Bank) }\end{array}$ & $1992-1995$ & $\begin{array}{l}\text { Török László } \\
\text { (CIB Bank) }\end{array}$ & 2008-2009 \\
$\begin{array}{l}\text { Felcsuti Péter } \\
\text { (Raiffeisen Bank) }\end{array}$ & $1995-2001$ & $\begin{array}{l}\text { Patai Mihály } \\
\text { (UniCredit Bank) }\end{array}$ & 2009-2011 \\
$\begin{array}{l}\text { Matthias Kunsch } \\
\text { (HVB Bank) }\end{array}$ & 2001-2005 & $\begin{array}{l}\text { Becsei András } \\
\text { (OTP Jelzálogbank) }\end{array}$ & 2014- \\
\hline
\end{tabular}

\begin{tabular}{llll}
\hline \multicolumn{3}{c}{ Főtitkárok } \\
\hline Radnótzi János & 1989 & Nyers Rezső & 2000-2011 \\
Pulai Miklós & $1989-2000$ & Kovács Levente & 2011- \\
\hline
\end{tabular}

\begin{tabular}{llll}
\hline \multicolumn{3}{c}{ Főtitkárhelyettesek } \\
\hline Fodor György & $1990-2001$ & Móra Mária Tünde & 2001-2018 \\
Marsi Erika & 2001 & Vass Péter & 2018- \\
\hline
\end{tabular}




\begin{tabular}{lll}
\hline & \multicolumn{1}{c}{ Elnökségi tagok* } \\
\hline Balázs László & Harmati László & Nátrán Roland \\
Bánki Frigyes & Hegedüs Éva & Papp Edit \\
Bernáth Tamás & Heinz Wiedner & Pázmándy Gyula \\
Czirják Sándor & Hendrik Scheerlinck & Radovan Jelasity \\
Csányi Sándor & Hernádi Zsolt & Sean Morrisey \\
Csicsáky Péter & Iványi György & Simák Pál \\
Egyed Géza & Kolossváry Ádám & Terták Elemér \\
Erős János & Lendvai János & Török László \\
& Lenk Géza & Urbán Zoltán \\
Gergely Károly & Madarász László & Zdeborsky György \\
Gyuris Dániel & Medgyessy Péter & Zolnai György \\
& Morgós Katalin & \\
\hline
\end{tabular}

\section{A Magyar Bankszövetség munkatársai*}

\begin{tabular}{lll}
\hline Antalóczy Györgyné & Gyenese Éva & Pirkmayer Mária \\
Auer Katalin & Hámori Réka & Polgárdy Lórántné \\
Batka Anna & Hegedűs István & Rácz Emese \\
Csillik Péter & Herceg Károly & Rónaszáki Bella \\
Dávid Sándor & Juhász-Nagy Anita & Schőner Gábor \\
Deák Dávid & Kajtor-Wieland Ildikó & Sütő Ágnes \\
Farkas Józsefné & Köves Andrásné & Szalai Jánosné \\
& Ladányi Zoltán & Székely Veronika \\
Forgács Magdolna & Martonovics Bernadett & Szilágyi Noémi \\
Földi Tamás & Móra Mária Tünde & Szőcs Gábor \\
Garbainé Kovács Katalain & Müller János & Takóné Egyed Orsolya \\
Gyárfás Judit & Orbán Olimpia & Török László \\
& Osváth Piroska & \\
\hline
\end{tabular}

Megjegyzés: *Vastagított szedéssel jelöltük a 2019-ben aktív elnökségi tagokat, illetve munkatársakat. 


\section{A Magyar Bankszövetség tagjai (2019)}

AEGON Magyarország

Lakástakarékpénztár

Agrár-Vállalkozási

Hitelgarancia Alapítvány

Bank of China

(Hungária) Zrt.

Bank of China

Hungarian Branch Zrt.

BISZ Zrt.

Budapest Bank Zrt.

CIB Bank Zrt.

Citibank Europe plc.

Magyarországi Fióktelepe

Cofidis Magyarországi

Fióktelepe

Commerzbank Zrt.

Deutsche Bank AG

Magyarországi Fióktelepe

Diákhitel Központ Zrt.*

Duna Takarék Bank Zrt.

\section{Magyar Cetelem}

Bank Zrt.

Magyar Fejlesztési

Bank Zrt.

MagNet Magyar

Közösségi Bank Zrt.

Magyar Államkincstár

Eximbank Zrt.

NHB Bank Zrt.

Oberbank AG

Magyarországi Fióktelepe

OTP Bank Nyrt.

OTP Jelzálogbank Zrt.

OTP Lakástakarék Zrt.

Polgári Bank

K\&H Jelzálogbank Zrt. Porsche Bank Zrt.

KDB Bank Európa Zrt.

Pénzügyi Vállalkozások

Országos Egyesülete

Raiffeisen Bank Zrt.

Sberbank

Magyarország Zrt.

Sopron Bank Zrt.

Takarébank Zrt.

Takarék Jelzálogbank

Nyrt.

Erste Bank Hungary Zrt. Magyar Lízingszövetség*

Takarék Kereskedelmi Bank Zrt.

Erste Jelzálogbank Zrt. Merkantil Bank Zrt.

UniCredit Bank

Hungary Zrt.

UniCredit

Erste Lakástakarék Zrt. MKB Bank Zrt.
Jelzálogbank Zrt. 
A korábban említett, áldozatos munkákért, szerepvállalásért hálás köszönettel tartozunk mindazon több tízezer hüséges banki munkatársnak, akik az elmúlt három évtizedben munkájukkal helytálltak, aktivitásukkal segítették a magyarországi bankszektor létrehozását, felépítését és eredményes munkáját. Ezzel döntő szerepet vállaltak az elmúlt időszak hazai gazdasági fejlődésében és eredményeiben.

Összefoglalásul és zárásul egy Kölcsey-gondolatot idézünk:

„Minden pálya dicsö, ha belöle hazádra derül fény!”

\section{HIVATKOZÁSOK}

A Magyar Bankszövetség Alapszabálya, http://bankszovetseg.hu/Content/alapdokumentumok/ HATALYOS_alapszabaly_magyar.pdf (letöltve: 2019. január 14.)

Előjegyzési Napló az 1940. évre (1939): Takarékpénztárak és Bankok Egyesülete, XIX. évfolyam, TÉBE.

Kovács Levente (2017): Pénzügyi szektor a bizalmatlanság markában. In: Kovács Levente - SiPos JózSEF (szerk., 2017): Ciklusváltó évek, párhuzamos életrajzok. Budapest, Semmelweis Kiadó.

Müller János - Kovács Tamás - Kovács Levente (2014): A Magyar Bankszövetség története Budapest, Tarsoly Kiadó.

VÉRTes István (1940): Szociálpolitikai előadások a TÉBE közgyűlésén. Szociális Szemle I. évf. 5. sz. (1940. V. 1., http://mtdaportal.extra.hu/ADATTAR/cikktar/v_cikk/vertes_istvan_ szocialpolitikai_eloadasok_a_tebe_kozgyulesen.pdf (letöltve: 2019. január 19.).

Patai Minály (2011): Már közel a megállapodás a kormány és a Bankszövetség között. Napi.hu, https://www.napi.hu/magyar_vallalatok/kozel_a_megallapodas_a_kormany_es_a_ bankszovetseg_kozott.504747.html (letöltés ideje: 2019. január 15.).

PÁl Zsolt (2013): A bankközi klíringforgalom időbeli megoszlása. Hitelintézeti Szemle, 12(6), 515534.

Pethő Tibor (2008): Mecénások - 70 éves a Magyar Nemzet. Magyar Nemzet, október 21., http:// mno.hu/migr_1834/mecenasok-347119 (letöltés ideje: 2019. január 15.).

2 Kölcsey Ferenc (1833): Versenyemlékek 